\title{
"Can't stop the boy"*: Philip Morris' use of Healthy Buildings International to prevent workplace smoking bans in Australia
}

\author{
S Chapman, A Penman
}

Tobacco Control 2003;12(Suppl III):iii107-iii 112

See end of article for authors' affiliations

Correspondence to: Professor Simon Chapman School of Public Health,

University of Sydney,

Building A 27, Sydney,

NSW 2006, Australia;

simonchapman@

health.usyd.edu.au

\begin{abstract}
Objective: To document the relationship of the indoor air consultancy company Healthy Buildings International (HBI) with the Australian tobacco industry.

Design: Systematic keyword and opportunistic website searches of tobacco industry internal documents made available through the Master Settlement Agreement.

Results: Since $1987 \mathrm{HBI}$ has played a high profile role in advancing the Australian tobacco industry's concerns to prevent building owners introducing smoke-free workplaces by advocating for ventilation solutions. HBl invoiced Philip Morris' US lawyers Covington and Burling for work undertaken in Australia and sought to publicly deny its association with the industry. $\mathrm{HBI}$ breached Standards Australia protocols in providing PM with confidential public submissions made to a review of the Australian standard on ventilation and acted as an undeclared cipher into the review for Philip Morris's concerns, leading to the eventual dismissal of the $\mathrm{HBI}$ representative from the standards subcommittee.

Conclusions: $\mathrm{HBI}$ in Australia exemplifies the tobacco industry's use of third party strategy in publicly advancing a case against smoke-free indoor air.
\end{abstract}

n a Sydney suburb, a small office houses Healthy Building International Pty Ltd (HBI). The company's website describes its business as "indoor environmental consultants" and explains:

\begin{abstract}
"Established in Sydney in 1987 and majority Australian owned, $\mathrm{HBI}$ provides a range of consulting services to most of Australia's leading property owners and managers. Our client list includes Local, State and Federal Governments, life insurance companies, banks, universities, real estate companies, licensed clubs and other large commercial and industrial concerns across the continent... $\mathrm{HBI}$ provides expert advice and when unavoidable, testimony to assist clients avoid potentially damaging litigation."
\end{abstract}

However, as of 16 July 2003, the site said nothing about one of HBI's most enduring and important clients-indeed the client responsible for its establishment in Australia-the tobacco industry. In this case study, we review the history of HBI's relationship with the Australian tobacco industryalmost exclusively Philip Morris (PM) - showing that as has occurred throughout the world, one of the industry's principal strategies was to engage third parties to run its messages before the public and other significant stakeholders. PM Australia's 1996 strategy on combating environmental tobacco smoke (ETS) policy stated: "promote the concept of Total Air Quality Management through a wide variety of third parties." ${ }^{2}$ HBI is an outstanding example of the way this was played out.

\section{METHODS}

The data for this paper came from primary and secondary document sites on the web arising from litigation in the USA

*Hodgson R. [Fax to M. Pottorff]. 3 March 1992. Philip Morris. Bates No. 2025835299. http://legacy.library.ucsf.edu/tid/lyy83e00.
The search string (pagewood or moorabbin or granville or australia or sydney or melbourne or brisbane or hobart or adelaide or perth or canberra or amatil or wills) has been used throughout the project to gather documents relating to the Australian market. The documents thus obtained were then searched for any mentions of Healthy Buildings International, HBI, or "Joe Robertson". An overview of our approach to document searching and analysis is found in the introduction to this supplement.

\section{RESULTS}

In 1993, US journalist Myron Levin wrote a major exposé of $\mathrm{HBI}^{\prime} \mathrm{s}$ activities in the USA, ${ }^{3}$ exposing PM's support for the company and the importance placed on having a seemingly independent third party do its public talking: "Rich but reviled-and unable to speak effectively for themselves-they were ready to throw money in the path of anyone whose pronouncements on the subject might bring relief... [director Gray] Robertson's message was carried in scores of newspaper and broadcasting interviews. People [the US popular magazine], ran a feature spread calling Robertson 'the building doctor'... With the help from the cigarette makers Robertson raised his professional stature and became the closest thing to a media celebrity in the indoor pollution field." The US company produced a high production quality magazine Healthy Buildings International Magazine, partly funded by PM, ${ }^{4}$ and estimated to cost between \$US500 000 to $\$ 750000$ a year; as Levin says, "a pricey promotion for a business the size of HBI whose total sales were \$1.2 million in $1986^{\prime \prime}{ }^{3}$

Abbreviations: BAT, British American Tobacco; BOMA, Building Owners and Managers Association; ACVA, Air Conditioning and Ventilation Associates; ETS, environmental tobacco smoke; HBI, Healthy Buildings International; IAQ, indoor air quality; PM, Philip Morris; TIA, Tobacco Institute of Australia 
Barnes et $a l^{5}$ report that in the USA, a 1994 staff report prepared by the House of Representatives Subcommittee on Health and the Environment summarised evidence suggesting that a study conducted by HBI contained fabricated and falsified data. ${ }^{67}$ The HBI study sought to measure levels of ETS in typical office environments and concluded "with good ventilation, acceptable air quality can be maintained with moderate amounts of smoking" ${ }^{8}$ A review commissioned by the US House Committee concluded that in the HBI study "the data is so marred by unsubstantiated data entries, discrepancies, and misclassifications that it raises serious questions of scientific fraud"67 and commenced legal proceedings. While the US Justice Department dropped its suit against HBI, citing lack of evidence, ${ }^{9}$ in 1998, a suit brought in 1993 by a former HBI employee, Jeffrey Seckler, under the False Claims Act (the "whistle-blower" statute), was settled out of court for \$US100 000 with tobacco companies funding the settlement and paying HBI's legal fees. The Act allows employees of private contractors to collect a portion of damages for exposing fraud against the US federal government. As part of the agreement filed in US District Court in Washington, Seckler admitted that HBI "to his knowledge" had not defrauded or filed false reports with its federal clients. ${ }^{10}$

While HBI internationally had also worked with British American Tobacco (BAT) on projects funded by several tobacco companies, in 1991 PM threatened to cut off HBI's funding if HBI worked for BAT without PM involvement, ${ }^{11}$ a decision which BAT's Sharon Boyse described to PM's Steve Parrish as "the most appalling situation... [with] ...implications...for the whole principle of industry cooperation on ETS issues" ${ }^{\prime \prime}{ }^{12}$ Other than BAT Australia citing HBI material in their public documents, we found no evidence that HBI worked for any tobacco company other than PM in Australia.

\section{HBI's message}

HBI's major message is consistent with a core platform of the tobacco industry's global strategy on ETS: promulgate the view that tobacco smoke is a trivial and insignificant part of indoor air pollution, and that the solution to improving indoor air quality (IAQ) said to arise from smoking lies with ventilation solutions rather than bans on smoking, thereby allowing smoking to continue in indoor environments. HBI was to become a key part of PM's global and Australian efforts to develop "a strategy to focus the issue on IAQ, not on ETS...which can be done effectively only by other groups". ${ }^{13}$ In 1995, PM's budget for worldwide regulatory affairs, including efforts to stop ETS control initiatives, was $\$ 91476000$, and HBI was listed among dozens of agencies which would receive "more than $\$ 50000$ " to assist with their efforts. $^{14}$ Today HBI's Australian website states: "Environmental tobacco smoke has become a hot topic. Dealing with smoking indoors requires some thought. How to keep the air clear for non-smokers without exiling the smokers to the streets? HBI offers some practical guidelines." ${ }^{1}$ These focus on ventilation and designated smoking areas.

\section{$\mathrm{HBI}$ in Australia}

In February 1987, the tobacco industry moved to set up an Australian branch of Air Conditioning and Ventilation Associates (ACVA) Atlantic (later to change its name to $\mathrm{HBI}$ ). The Tobacco Institute of Australia (TIA) "conducted preliminary talks with Mr. [Gray] Robertson about opening an Australian branch of his firm. At week's end, Mr. Robertson and his brother [Joe], who resides in Sydney and would manage the branch, had shaken hands on an agreement whereby the TIA would provide seed money and a consulting contract with the firm. In turn the branch, ACVA Pacific, would work much in the same way as it does in the United States-analyzing and improving the environmental quality of buildings in Australia and speaking out publicly on the issue of ETS". ${ }^{15}$

PM organised ETS seminars in Sydney and Melbourne in the week of 23 February 1987 using a team of consultants comprising HBI's Gray Robertson John Rupp, the Covington and Burling $(\mathrm{C} \& \mathrm{~B})$ lawyer, and regular tobacco industry consultant Philip Witorsch. ${ }^{15}$ The consultants made a presentation to journalists "representing all major newspapers in the country". For PM, highlights of the Australian tour were "The media session and follow-up one-on-one interviews generated 9 stories in daily newspapers. Only one was negative... Several positive radio and TV interviews were conducted as well...". ${ }^{15}$

A key Australian PM document from 1991 set out the objectives PM held for HBI, its activities and plans. "The key objective of the HBI concept is to broaden the debate on indoor air quality to deflect the ETS challenges and to gain acceptance of a systems approach to maintaining indoor air quality." HBI's key strategies were: targeted distribution of the US produced HBI magazine; targeted audience seminars; maximising media coverage, especially in the trade press; conducting indoor air quality tests in high profile buildings and publicising the results of these tests. The report noted: "It would appear that the HBI concept has measurably achieved the key objective- 'to broaden the debate on IAQ and deflect the ETS challenges'. Confirmation of this achievement can be found in the attached transcripts and articles where it will be noted how rarely ETS is mentioned...HBI is now positioned as an authority on IAQ issues. Joe R[obertson] has developed effective relationships with the most influential trade magazines...". ${ }^{16}$

Discussing plans, the document continued: "Seminars ... could then lead to commissions for HBI. The objective would be to focus on IAQ control and reduce the pressure for smoke-free workplaces. We should also maximise HBI's high profile on the IAQ issue by encouraging Joe R. to take up every appropriate speaking engagement. Additionally, he should respond to all 'negative' IAQ media reports." ${ }^{16}$

Between 1987-1992, the PM document archives contain many invoices for payments for HBI Australia for attending and speaking at a wide variety of conferences, assisting PM with reports and submissions, distributing the HBI magazine in Australia and in the South East Asian region, and conducting a public relations campaign in association with Edelman Public Relations at a cost of $\$ 100000 .{ }^{17}{ }^{18}$ In the early period, the Australian branch arranged for HBI in the USA to invoice PM's lawyers C\&B for the Australian branch's costs and charges-typically \$US1000 a day. C\&B then consolidated HBI invoices, passing them to PM USA. ${ }^{19}$ This presumably carried the advantage of allowing HBI (should it ever be questioned) to deny that it received money from either the Australian or US tobacco industry. PM's policy was to "avoid direct involvement with consultants actively working with either C\&B or SH\&B [Shook Hardy and Bacon, another PM law firm]. Work with these consultants should be thru respective law firms." ${ }^{20}$ Potential Australian questioners would have been unlikely to ask whether a US law firm was paying the company. PM in Australia kept the New York office regularly informed about HBI's activities, with letters often containing candid remarks about how happy they were with Robertson: "We keep the pot boiling as best we can." ${ }^{21}$

Examples of HBI's Philip Morris supported presentations to Australian conferences include:

- Seminars in state capitals, February $1991^{22}$ 
- Australian Society for Environmental Medicine, Brisbane 12-13 July $1992^{23}$

- Clean Air Society of Australian and New Zealand, 7-8 July $1992^{23}$

- Hotel Engineers Conference, Gold Coast November $1992^{24}$

- Australian Institute of Environmental Health, October $1991^{25}$

- Association of Corrosion Engineers, November $1992^{26}$

- Trane Air conditioning Clinic, June $1992^{23}$

- Sick Building Seminar, Sydney November 1992. ${ }^{27}$

Details of what was said at those seminars is not available, or if any acknowledgement was made in regard to PM support, or if the organisers were aware of PM support for the HBI presentations.

In a speech to the Building Owners and Managers Association (BOMA) in 1993, Joe Robertson opened his presentation by stating: "...if I were to present exactly the same data on behalf of the tobacco industry I would be more than likely branded as an apologist for the tobacco industry...it is important that you understand that I am not here at the expense or invitation of the tobacco industry nor am I an apologist for that industry." ${ }^{28}$ He continued: "The findings, statements and recommendations that [HBI] discuss are based on independent research", and that "Whenever we enter a new market we find it expedient to retain the services of a company such as Harris Research Centre, who conduct public opinion polls." ${ }^{28}$ Robertson made no mention that much of the research HBI discusses is funded by the tobacco industry and that PM had paid for him to publicise the results of the Harris poll. ${ }^{29} 30$

No evidence has been located to show that Robertson was paid by the tobacco industry for this particular BOMA presentation. But it is reasonable to assume that many in the audience would have taken his statement to mean that HBI had no connection with the industry and its US legal firms, which was certainly not the case.

Any notion that HBI's ETS-dousing work was somehow independent of PM's patronage is dispelled by a memo describing how Robertson passed requests for speaking engagements through to PM for its approval: "JR receives numerous high quality speaking opportunities. He accepts those we agree on...He is a 'potent' consultant and we should make the most of him." ${ }^{\prime \prime 1}$ By 1992 Joe Robertson was doing such a good job for PM in Australia that PM's Reg Hodgson wrote to PM New York's Mary "Mopsy" Pottorff asking "if you have been able to slot JR into the "International Consultants" budget. He has had another top speaking offer, and as we both agree, we want him to do such things". ${ }^{32}$ Another PM memo exclaimed that they "Can't stop the boy". ${ }^{33}$ HBI regularly stressed in their reports and invoices that their activities generated "unprecedented follow-up meetings with media" ${ }^{29}$ and "unbelievable media". ${ }^{31}$

In June 1992, Australian television ran a story about an NBC report revealing that PM owned a large stake in HBI. ${ }^{34}$ With HBI being always at pains to present themselves as independent experts, the reports may have caused concern about how to explain their relationship to the tobacco industry. In August 1992, PM's Reg Hodgson wrote to PM in New York: "Obviously, the current discussions on "acknowledgement" are of concern to both gentlemen" [Gray and Joe Robertson]. "It is an issue that needs to be resolved...".35 By 1994, PM Australia's planned budget for work involving HBI in Australia was \$200 000.. ${ }^{36}$

\section{Influencing Australian standards for indoor air}

Standards Australia is a national non-government body responsible for the development of a wide range of design and production standards. Some of these standards are adopted into legislation or industry codes such as the Building Code of Australia.

In 1991 Standards Australia published AS1668.2: The use of mechanical ventilation and air conditioning in buildings. Part 2 Mechanical ventilation for indoor air quality.

The 1991 standard was a health and amenity standard, which set ventilation rates based on factors which included the then current assessed levels of smoking for various types of building occupancies. There is no specific reference to the standard dealing with the health effects of smoking. Overall, a guiding principle appears to have been that dealing with odours and indoor pollutants in general to levels acceptable to the community would be sufficient to deal with health effects. It is not known if HBI was involved in the preparation of the 1991 standard.

The standard assumed critical significance in tobacco control when it was incorporated by the Australian Capital Territory into its 1995 legislation making bars and restaurants smoke-free. The compromise in this Australian landmark legislation was the granting of exemptions to specific areas of bars and restaurants, which could demonstrate that they ventilated premises to the level required by this standard. Health interest groups were concerned that the ventilation standard was being used inappropriately as a de facto health standard for ETS and that this could set a precedent for other jurisdictions considering legislation to ban or restrict ETS.

At about this time, Standards Australia established a subcommittee to review the 1991 ventilation standard. Chris Salmon from HBI was a member of the subcommittee.

The proposed new standard charted a different course. The draft for public comment provided minimum mechanical ventilation rates for virtually all building enclosures based on both smoking and non-smoking designations. In smoking permitted venues, the ventilation rates were claimed to have a health basis. It also included for the first time provision for natural ventilation, including design criteria for naturally ventilated smoking permitted areas. Health groups were particularly concerned about the effect on legislation which called up the standard such the previously mentioned legislation from the Australian Capital Territory. They foreshadowed exemptions from smoking bans being granted to hotels with natural ventilation only-that is, windows and doors that could open-whereas mechanical ventilation was previously required.

The tobacco industry had a clear interest to ensure that there was no deterioration for smoking permitted premises in the way the new standard dealt with ETS, while maintaining the illusion that it was possible to have a health basis for ventilating smoking permitted areas.

The draft was strongly opposed by health interest groups and health authorities. Partly in response to these health concerns, the NSW Health Department joined the subcommittee in 1997 (a role played by the second author through 1998).

By 1996, HBI was confident that the committee's recommendations on reform of the standard would reflect PM's agenda almost perfectly. It reported progress to PM Australia who advised its head office: "...that the revised standard *will allow for natural and mechanical ventilation ...*should still enable building owners and managers to accommodate smokers and smoking areas without making the requirements so onerous as to be impractical or overly expensive. In fact HBI believes that most existing building will easily be able to provide smoking areas without altering their ventilation systems." ${ }^{\prime 37}$ Significantly, the industry's preoccupation with the impact of smoking restrictions on consumption remained to the fore: "We have asked HBI to 
prepare a report focusing specifically on the impact the proposed changes might have on smoking. ${ }^{\prime 37}$ HBI's subsequent report brought good news: "...the proposed changes to the [Australian] standard will not have a significant effect on smoking in buildings and, in some instances, will make it easier for bars and restaurants to permit smoking and comply with the standard." ${ }^{\prime 38}$

As the work of the subcommittee became more widely known, criticism from health groups increased. As a result, the draft standard was modified to specify smoking abatement as the primary control over ETS, and to emphasise that the "smoking permitted" provisions of the standard were based only on amenity (comfort), and not on health criteria. It proposed an alternative health based section on ETS, the purpose of which would be to permit calculation of the ventilation rates required to reduce the mortality risk from ETS to any predetermined level. The approach was novel, although it involved many assumptions and interpolations into the available data. Additionally, as any generally accepted level of residual population risk would require heroic (and very expensive) levels of ventilation, the incorporation of any such section in the body of the standard would have been devastating to tobacco interests.

These proposed changes continued the controversy on all sides. Health interests were concerned that the draft standard would provide legislated sanction to any degree of ETS exposure. HBI opposed details of the ETS risk calculations, ${ }^{39}$ while tobacco industry papers demonstrate their anxiety about any risk calculations being incorporated into a regulatory standard. This prolonged the work of the subcommittee for years, and resulted finally in the health based ETS risk calculations being relegated to an informative non-binding appendix entitled a Passive smoking harm index. The gain for the tobacco industry was that even with the latest changes to the draft standard, the previous HBI advice may still have been valid - that is, the standard would not have a significant effect on smoking in buildings, and in some cases it might be easier for bars and restaurants to permit smoking and comply with the standard. The outcome for health groups has been to discredit ventilation and the standard as suitable tools for regulating ETS.

The standard was eventually published in 2002 as AS 1668.2-2002: The use of ventilation and airconditioning in buildings_-Ventilation design for indoor air contaminant control.

Largely because of concerns of health authorities, the 2002 standard has not been called up in the Building Code of Australia, which still refers to the 1991 version.

\section{HBI as PM's cipher}

$\mathrm{HBI}^{\prime} \mathrm{s}$ long standing representative on the subcommittee that most recently revised the standard from the mid 1990s was its employee Chris Salmon. In 2002, he told a newspaper that he was "never directed in any particular way to make any particular statement to the committee... The reason I was there was because of my expertise in indoor air quality". ${ }^{40}$ Salmon reported to his employer Joe Robertson but claimed he was "not aware" of a report made by HBI to PM or that HBI was a consultant to the tobacco company. ${ }^{40}$ These statements make an interesting contrast with evidence from the documents which show HBI and Salmon had discussions with PM in 1998-99 when the subcommittee was considering the health based ETS risk calculations as part of the other changes the ventilation standard. ${ }^{41-43}$

In 1998, Gray Robertson wrote to PM in New York that Salmon "has looked after our interests there very well" but then went on to note that the HBI's and PM's positions on ETS were only "coincidentally" supportive of each other: "Anytime anyone from HBI appears to support issues that coincidentally support the position of your company [that is,
PM] we must accept all sort of snide comments from the Health Departments and the IAQ Organizations. We become targets of every tobacco related press article, thus we have to be thick skinned to survive. How frustrating it is when immature, uneducated and unsubstantiated criticisms are then flung at us by 'butterflies' who pass through one day every few years. When this happens the incentive to continue working with this endeavor is rapidly lost." ${ }^{44}$

However, if Gray Robertson believed HBI's and PM's interests were merely "coincidental", Mark Friedman (head of PM's regulatory affairs for Asia, Australasia, and Japan), seemed to have other views and regarded Salmon as a cipher for PM's views to be put to the committee without naming their source. Providing others in PM with leaked material ("a bundle of correspondence, which should be treated as highly confidential, regarding recent developments concerning the Australian ventilation standard"), Friedman stressed: "Unfortunately, Chris Salmon, the HBI employee who is a member of the Standards Sub-Committee, cannot attend the November 4 meeting. Accordingly, he needs input by the end of this week so that some form of the submission can be made in advance of the meeting." 45

While not himself being a member of the subcommittee, as shown by fax numbers on documents, Joe Robertson leaked information to PM in 1998 (presumably provided by Salmon) stressing it was "a confidential document which should be handled with extreme discretion". ${ }^{46}$ And again, in March 1999, Robertson forwarded to PM several confidential submissions made by various health groups and citizens to the subcommittee. ${ }^{47-54}$ In February 1999, Robertson sent PM a copy of a Standards Australia postal ballot draft of the new ventilation standard, inviting them to contact Salmon to discuss it. ${ }^{55}$ HBI later also faxed PM a copy of Chris Salmon's completed ballot paper on a Standards Australia postal vote. ${ }^{56}$

The earliest known subcommittee document in the PM archive is an early draft of the standard marked "Draft for Committee Purposes only, Second Committee Draft, Issued August 1995". There is no indication on this document of how it came into PM's possession. ${ }^{57}$

The development of Australian Standards is in general characterised by confidentiality of committee working papers and submissions. ${ }^{58}$ In November 2002, after having been provided with evidence of Joe Robertson's provision of confidential information to PM, Standards Australia removed HBI from membership of the subcommittee and changed the title of the standard "to ensure that it clearly does not cover the health effects of tobacco smoke".59

\section{"We advise the US EPA"}

In September 2001, Joe Robertson participated in a debate with the first author at the annual conference of the NSW Registered Clubs Association in Tweed Heads. Speaking in the debate before Robertson, the first author [SC] challenged him to state whether he was a consultant to the tobacco industry and fanned in front of the audience a large folder of HBI's invoices to C\&B. Robertson replied: “My company has been appointed the sole guy [sic] to indoor air quality matters to the United States government. A five year contract...five year renewable, and we advise the US EPA and we advise their courts and we've done that successfully for 20 years." [transcript of videotape]

A search of the US Environmental Protection Agency website suggests something rather different. One hundred and thirteen companies or institutions are listed as "partners or allies" of the EPA's Air Protection Division who had received energy efficiency awards. The officer in charge of the EPA's Indoor Environments Division emailed the first author on 31 May 2002 that a check of her staff and with "the key person on tobacco in our Office of Research and 


\section{What this paper adds}

The international tobacco industry has long sought to use seemingly independent third party individuals and agencies to promote its views because of credibility problems involved in the industry itself promoting self interested policies. Healthy Buildings International has been a key example of this strategy, particularly in the USA.

The Tobacco Institute of Australia assisted in the establishment of Healthy Buildings International Australia via a seeding grant in 1987. HBI has since played a high profile role in advancing the tobacco industry's concerns to avoid building owners introducing smoke-free workplaces by advancing ventilation solutions. $\mathrm{HBI}$ breached Standards Australia protocols by providing Philip Morris with confidential public submissions made to a review of the Australian standard on ventilation and acted as an undeclared cipher into the review for Philip Morris' concerns.

Development" had confirmed "None of us are aware of any work that HBI has with EPA." ${ }^{\prime \prime 0}$

\section{CONCLUSION}

While promoting itself as a fully independent indoor air quality consultancy, since its inception HBI Australia has had a major financial relationship with PM both directly and via its US based law firm Covington and Burling. During this time, its principal in Australia, Joe Robertson, promoted an agenda that was consistent with PM's international goal of maintaining tolerance for indoor smoking, and focusing any control efforts around ventilation solutions rather than the adoption of smoke-free working environments. Robertson's participation in many Australian meetings was vetted directly by PM, which keenly monitored his efforts and their reportage in the news media and enthusiastically communicated this to its US head office.

HBI staff acted as PM's undeclared agent of influence on a national review of the Australian standard on ventilation. It supplied PM with submissions made to this review, in contravention of Standards Australia policy. Both HBI and PM understood the impropriety of HBI having supplied these submissions, as evidenced by their mutual emphatic concerns that their exchanges be keep strictly confidential.

However, HBI has been a significant player since 1987 in both its contribution to public statements made about the alleged trivial contribution of ETS to indoor air quality, and to the key standard setting process that occurs in Australia regarding the indoor air quality in occupational and other public settings. In both these roles, HBI's actions were intended to retard the progress of tobacco control policies and practices that would have increased the adoption of smokefree work and public places.

\section{ACKNOWLEDGEMENTS}

The research reported in this paper was supported by grants from the National Health and Medical Research Council (2001-2003\#153857) and the US National Institutes of Health (2001-2005\#R01CA871100lAl)

\section{Authors' affiliations}

Simon Chapman*, School of Public Health, University of Sydney, New South Wales, Australia

Andrew Penman, Cancer Council, New South Wales, Australia

\section{REFERENCES}

1 Healthy Buildings International Pty Ltd. Indoor Environmental Consultants: Leaders in indoor environmental consulting. http://www.hbi.com.au/ whoarewe.html [Accessed 4 June 2002]

2 Philip Morris USA, Philip Morris International. Ensuring reasonable smoking policies by accommodating the preferences of smokers and nonsmokers: worldwide strategy and plan: draft. 14 October 1996. Philip Morris. Bates No. 2060577485/7564. http://legacy.library.ucsf.edu/tid/jaal3e00

3 Levin M. Who's behind the building doctor? The Nation 1993; Aug 9/16, 168-71.

4 Philip Morris International. Philip Morris statement for NBC. 10 June 1992. Philip Morris. Bates No. 25001 16610. http://legacy.library.ucsf.edu/tid/ kkd42e00

5 Barnes DE, Hanauer P, Bero LA, et al. Environmental tobacco smoke: the Brown and Williamson documents. JAMA 1995;274:248-53.

6 House Subcommittee on Health and the Environment. Environmental tobacco smoke investigation: exhibits. Washington DC: Committee on Energy and Commerce, US House of Representatives, 1994.

7 House Subcommittee on Health and the Environment. Oversight hearing on tobacco product regulation. Washington DC: Committee on Energy and Commerce, US House of Representatives, 1994

8 Turner S, Cyr L, Gross A. The measurement of environmental tobacco smoke in 585 office environments. Environ Int 1992;18:19-28.

9 Schmitt R. U.S. won't charge firm in smoking case. Wall Street Journal 1996; Dec 11. http://www.globalink.org/tobacco/docs/ets/9612scrc.shtml (Accessed 4 June 2002)

10 Levin M. Indoor-air consultant settles whistle-blower suit courts: ex-executive claimed Healthy Buildings International was front for tobacco companies. Los Angeles Times 2 July 1998. http://www.globalink.org/tobacco/docs/ets/ 9909hbi.shtml (Accessed 4 June 2002)

11 Boyse S. [Fax to JR Basso-Dastugue, Nobleza-Piccardo]. 13 November 1991 British American Tobacco. Bates No. 304058460. http:// tobacco.health.usyd.edu.au/tds/BAT304058460 (Accessed 20 January 2003)

12 Boyse S. [Fax to S. Parrish, Philip Morris]. 12 November 1991. British American Tobacco. Bates No. 304058461/8462 http:// tobacco.health.usyd.edu.au/tds/BAT304058461_8462 (Accessed 20 Jan 2003)

13 Philip Morris (Australia) Limited. 2RF presentation to W.H. Webb (elongated version-not presented). 27 May 1993. Philip Morris. Bates No. 2504200049/0081. http://legacy.library.ucsf.edu/tid/Ifn32e00

14 Philip Morris. Worldwide Regulatory Affairs 1995 original budget: draft. 26 October 1994. Philip Morris. Bates No. 2065424232/4277. http:// legacy.library.ucsf.edu/tid/tep94c00

15 Badler R. ETS Seminars Australia, 23-27 February, Hong Kong, 2-6 March. 10 March 1987. Philip Morris. Bates No. 2021001983/1987. http:// legacy.library.ucsf.edu/tid/kbi88e00

16 The HBI concept. 1991. Philip Morris. Bates No. 2023920795/0798. http:// legacy.library.ucsf.edu/tid/urf34e00

17 Robertson G. Invoice Australian seminar-Phase II Post Building Studies (Part two). Healthy Buildings International Inc. 8 August 1991. Philip Morris. Bates No. 2024525986. http://legacy.library.ucsfedu/tid/tii35e00

18 Robertson G. Invoice Australian seminar-Phase II Post Building Studies. Healthy Buildings International Inc. 15 July 1991. Philip Morris. Bates No. 2024525964. http://legacy.library.ucsf.edu/tid/iii35e00

19 Covington \& Burling. To cover the statement of Healthy Buildings International relating to the sampling and analysis during 1991 of buildings for their VOC content (37 in United States, 7 in Australia). 5 September 1991. Philip Morris. Bates No. 2029378167. http://legacy.library.ucsf.edu/tid/imr42e00

20 Pottorff M. S\&T Neuchatel. 24 Setpember 1991. Philip Morris. Bates No. 2023131664/1667. http://legacy.library.ucsf.edu/tid/pxi48e00

21 Hodgson R. [Fax to M. Pottorff]. 31 January 1992. Philip Morris. Bates No. 2025835206. http://legacy.library.ucsf.edu/tid/war95e00

22 Robertson G. [Invoice to Covington \& Burling]. Healthy Buildings International Inc. 9 January1991. Philip Morris. Bates No. 2029377299/7300. http:// legacy.library.ucsf.edu/tid/rhz98e00

23 Robertson G. HBI-Australia [invoice]. Healthy Buildings International Inc. 23 July 1992. Philip Morris. Bates No. 2029371099/1 104. http:// legacy.library.ucsf.edu/tid/oua09e00

24 Robertson G. Australia [invoice]. Healthy Buildings International Inc. 11 September 1991. Philip Morris. Bates No. 2029371292. http:// legacy.library.ucsf.edu/tid/gta09e00

25 Robertson G. HBI Australia [invoice]. Healthy Buildings International Inc. 26 November 1991. Philip Morris. Bates No. 2029377666. http:// legacy.library.ucsf.edu/tid/odz98e00

26 Hodgson R. JR update [Fax to M. Pottorff]. 5 March 1992. Philip Morris. Bates No. 2025835284. http://legacy.library.ucsf.edu/tid/par95e00

27 Robertson J. Invoice. Healthy Buildings International Pty. Ltd. 7 December 1992. Philip Morris. Bates No. 2029371293/1294. http:// legacy.library.ucsf.edu/tid/hta09e00

28 Robertson J. BOMA property law-property management seminar considering a tenant's well-being. Healthy Buildings International Inc. 3 June 1993. Philip Morris. Bates No. 2504203136/3154. http:// legacy.library.ucsf.edu/tid/nlj29e00

29 Robertson G. Harris Media Tour-Australia. Healthy Buildings International Inc. 22 March 1991. Philip Morris. Bates No. 2029377321/7322. http:// legacy.library.ucsf.edu/tid/ihz98e00

30 Robertson G. Invoice: Australia Harris Opinion Polls/Media Tour. Healthy Buildings International Inc. 25 February 1991. Philip Morris. Bates No. 2029370013/0014. http://legacy.library.ucsf.edu/tid/wxz98e00 
31 Hodgson R. [Fax to M. Pottorff]. 5 February 1992. Philip Morris. Bates No. 2025835204/5205. http://legacy.library.ucsf.edu/tid/var95e00

32 Hodgson R. Joe Robertson. 13 February 1992. Philip Morris. Bates No. 2025835210. http://legacy.library.ucsf.edu/tid/tar95e00

33 Hodgson R. [Fax to M. Pottorff]. 3 March 1992. Philip Morris. Bates No. 2025835299. http://legacy.library.ucsf.edu/tid/lyy83e00

34 Rehame Australia Monitoring Services. [Television Transcript Derryn Hinch Program, 11/06/1992]. 12 June 1992. Philip Morris. Bates No. 2024523037. http://legacy.library.ucsf.edu/tid/ggj35e00

35 Coventry M, Hodgson R. [Telex to Mary Pottorff]. 12 August 1992. Philip Morris. Bates No. 2025835278. http://legacy.library.ucsf.edu/tid/ hyy $83 \mathrm{e} 00$

36 Hodgson R. [Fax to M. Pottorff]. 22 September 1993. Philip Morris. Bates No. 2025837289/7292. http://legacy.library.ucsf.edu/tid/pny83e00

37 Windholz E. Revision of Australian ventilation standard. 11 July 1996. Philip Morris. Bates No. 2065279662. http://legacy.library.ucsf.edu/tid/ jdy77d00

38 Windholz E. Revision of Australian ventilation standard. 26 July 1996. Philip Morris. Bates No. 2065279672. http://legacy.library.ucsf.edu/tid/ ldy $77 \mathrm{~d} 00$

39 Salmon C. ME/062-0380-510 vote and comments [Fax to V. Aherne] Healthy Buildings International Pty Ltd. 26 February 1999. Philip Morris. Bates No. $2064831164 / 1166$. http://legacy.library.ucsf.edu/tid/mwb63c00

40 Pollard R. Smoke gets in their eyes over building rules. Sydney Morning Herald 13 November 2002;1.

41 Friedman M. Australian Ventilation Standard - Update. 10 February 1999. Philip Morris. Bates No. 2078445707. http://legacy.library.ucsf.edu/tid/ $\mathrm{xcn} 75 \mathrm{c00}$

42 Hodgson R. Australian standards [Email to R. Lau].Philip Morris Corporate Services Inc.(Australia, New Zealand, South Pacific). 13 November 1998. Philip Morris. Bates No. 2078446493. http://legacy.library.ucsf.edu/tid/ gqm75c00

43 Hodgson R. Facsimile ETS [Fax to R. Lau]. 28 October 1998. Philip Morris. Bates No. 2065254846. http://legacy.library.ucsf.edu/tid/kqq83c00

44 Robertson G. Australian Standards-Chris Salmon \& Matthias Schorp. Healthy Buildings International. 16 April 1998. Philip Morris. Bates No. 2072439561/9564. http://legacy.library.ucsf.edu/tid/ncc42c00

45 Friedman M. Australian Ventilation Standard. 29 October 1998. Philip Morris. Bates No. 2063786590/6591. http://legacy.library.ucsf.edu/tid/ $\mathrm{mziO4c00}$

46 Robertson J. ETS. Healthy Buildings International. 26 October 1998. Philip Morris. Bates No. 2505536501. http://legacy.library.ucsf.edu/tid/ Irn19c00
47 Hodgson R. [Facsimile to M. Friedman]. 9 March 1999. Philip Morris. Bates No. 2064831201. http://legacy.library.ucsf.edu/tid/fwb63c00

48 Meeuwissen S. Smoking in buildings. January 1999. Philip Morris. Bates No. 2064831 174. http://legacy.library.ucsf.edu/tid/twb63c00

49 Dodds J. [Letter to R. Wraight].Australian Department of Health and Aged Care. 16 February 1999. Philip Morris. Bates No. 2064831205/1206. http://legacy.library.ucsf.edu/tid/iwb63c00

50 McBride B. Standards Australia legal liability for air conditioning standard. Non Smokers Movement of Australia.22 February 1999. Philip Morris. Bates No. 2064831 155. http://legacy.library.ucsf.edu/tid/ilb63c00

51 Smith D. [Letter to P. Walsh].Australian Council on Healthcare Standards. 25 February 1999. Philip Morris. Bates No. 2064831 161. http:// legacy.library.ucsf.edu/tid/kwb63c00

52 Bicevskis M. [Letter to V. Aherne].Department of Health and Human Services, Tasmania. 26 February 1999. Philip Morris. Bates No. 2064831 162/1163. http://legacy.library.ucsf.edu/tid/lwb63c00

53 Walsh P. Revision of AS1668.2-1991, Mechanical ventilation for acceptance indoor - air quality. Standards Australia. 1 March 1999. Philip Morris. Bates No. 2064831222/1223. http://legacy.library.ucsf.edu/tid/rvb63c00

54 Grayson J. [Letter to R. Wraight]. WorkCover New South Wales. 22 December 1998. Philip Morris. Bates No. 2064831203/1204. http:// legacy.library.ucsf.edu/tid/hwb63c00

55 Robertson J. [Letter to R. Hodgson concerning the postal ballot draft for the Ventilation standard]. Healthy Buildings International Pty Ltd. 9 February 1999. Philip Morris. Bates No. 2063786429. http://legacy.library.ucsf.edu/ tid/abr87d00

56 Salmon C. Ballot paper for the adoption of ME/062-30810-510: The use of ventilation and airconditioning in buildings, Part 2, Ventilation design for indoor air contaminant control. Healthy Buildings International Pty Ltd. 26 February 1999. Philip Morris. Bates No. 2064831 167. http:// legacy.library.ucsf.edu/tid/nwb63c00

57 Standards Australia, Standards New Zealand. Draft Australian/New Zealand standard-The use of ventilation and airconditioning in buildings Part 2: Ventilation for acceptable indoor-air quality. August 1995. Philip Morris. Bates No. 2505536151/6257. http://legacy.library.ucsf.edu/tid/ ton 19c00

58 Standards Australia. Standardization guides and procedures. Standards Australia. https://committees.standards.com.au/POLICY/ [Accessed 11 July 2003].

59 Wraight R. [Letter from the Chief Executive, Standards Australia to N. Cothers, Australian Consumers' Association], 31 March 2003.

60 Smith M. [Email from the US EPA Indoor Environment Division to S. Chapman], 31 May 2002. 